\title{
Notes on the Origin of the Declared Account
}

$7 \mathrm{HE}$ so-called Declared Account is stated in Mr. Scargill1 Bird's official Guide to the Public Record Office ${ }^{1}$ to have been introduced about the reign of Henry VIII and to have been fully established by the reign of Elizabeth. It is also said that 'the Declared Account took the place of the old Compotus'.' An examination of Exchequer methods and controversies in the sixteenth and seventeenth centuries throws light on this transition and establishes the following points. It appears that the new system was directly connected with the addition to the establishment of the Exchequer by Elizabeth of two Auditors of the Prests. This addition was not merely an increase in the existing number of auditors, but was the creation by patent of a new office, and as such an important landmark in the history of an institution of highly conservative traditions. The erection of this office was also a return to the practice of the Court of Augmentations and Revenues established by letters patent of 39 Henry VIII and dissolved in 1553-4. Then certain differences between the earlier and the later system aroused opposition from the Exchequer officers, and were denounced by them as infringements of the 'Ancient Course' of the Exchequer. The later system by degrees overshadowed the earlier, which was concerned with types of account which became obsolete or gradually lost importance both relatively and absolutely. The old system, however, continued to exist, until both the old and the new methods were superseded by the Commissioners for Auditing Public Accounts. But it was only by degrees that the various stages in the passing of a 'Declared Account' in the Exchequer were established, and these stages were certainly not complete until the treasurership of Juxon (1636-41).

First, then, the distinction between the old Compotus and that form of account which was afterwards known as the Pipe and Audit Office Declared Account was a distinction between those accounts taken by the Auditors of the Exchequer, who were

1 p. 90, 3rd ed., 1908.

2 Public Record Office, Lists and Indexes, $\mathrm{x \times xv}$, Introduction. 
officials of long standing, and the Auditors of the Prests or Imprests. The term Declared Account was not used in this connexion; all accounts were declared in some form or other. The accounts passed in the new munner were differentiated as the Great Accounts, or the accounts taken by the Auditors of the Prests, or sometimes loosely as the Prest Accounts. ${ }^{3}$ The distinction is taken for granted by the writers on the Exchequer of this period.

There is a very valuable list, probably belonging to the year 1603 or 1604, in an Exchequer precedent book ${ }^{4}$ in which the accountants at the Exchequer are divided into two classes, those who account before the Auditors of the Exchequer and those who account before the Auditors of the Prests. It runs as follows :

\section{Accomptants accomptable in the Court of Exchequer}

[To] The auditors as well of ould Exchequer accomples as of the Revenues. ${ }^{5}$

The Master of the Rolles.

The Cofferer of the Kings Household.

The Treasurers Remembrancer for homage.

The Byshoppes for subsedyes of the Clergy.

The Sheriffes of every Countie.

The Escheators of the Countyes.

The Customers of the Portes for Customes and Subsedyes.

The Collectors of the tenthes subsedyes etc.

The Mannor of Woodstock.

The Maior and Company of the Staple.

The Coynager of the Mineralls Royall.

2.g. Lansdowne MS. 168, fo. 356. See the extract from Fanshawe cited below, p. 50. Howell, Londinopolis, p. 370, 1657, says : "There is the Auditor of the Preste whose Office it is to take the Accounts of the Mint Ireland and Barwick and of all other imprested or moneys advanc'd beforehand.' Cf. Blount's Law Dictionary, 1670: 'Auditor [sic] of the Prests or Imprests . . a are Officers of the Exchequer who take and make up the Great Accompts of Ireland Berwick the Mint and of any money imprested ....'

- Lord Treasurer's Remembrancer, Miscellaneous Books, 118, fo. 83.

- i. e. what were known as the Annexed Revenues and later as the Land Revenue. The seven auditors of the Exchequer who took the old Exchequer acconnts-that is, those accounts which were rendered in the manner of the old compotus, and aocording to the 'Ancient Course' of the Exchequer-also took the accounts of the land revenues which were "annexed" to the Crown on the diseolution of the Court of Augmentations and Revenues. Cf. Vernon, Considerations for regulating the Exchequer, 1642, p. 36 : 'The Seven Auditors of the Revenue who have in charge before them the Revenue annered to the Exchequer upon the dissolution of the Augmentation Cont anno 1 $M a r i z e$ and before whom the receivers genarall make their accompts according to their several assignments by their letters patent. . The other businesse which belongs to their place as they are Auditors or Clerkes in the Exchequer for taking the accompts of Sheriffs, Escheators, Customers, Comptrollers, Collectors of Subsidies, the Cofferers Accompt and the like, they have them by assignment from the Marshall of the Exohequer from time to time in open court....' 
The makers of broad glasse.

The mesne profitts of mannors lands etc for the forfeiture or seizure untill composition or pardon.

The Generall Receivors of his Hignes Revenue.

The Generall Receivor of the Dutchy of Cornwall.

The Customers of Portes for Pyrates goodes.

The Receavor of the Revennues of Byshopwrickes during the vacations.

The woodwardes of His Majesties woodes.

The feodaryes of honours.

[To] The Auditors of the Prestes.

The Treasurer of the Kinges Majesties Chamber.

The Treasurer of his Majesties Householde.

The Chiefe Butler of England.

The Master of the Great Warderobe.

The Master of the Jewell House.

The Master of the Rowles [? Revels].

The Master of the Tents and Pavillions.

The Postmaster.

The Lieuetenant of the Ordinance.

The Clerke of the Armory.

The Treasurer of Barwick.

The Treasurer of the marryne affaires.

The Surveyor of His Majesties victualls for his hignes navye.

The Kinges Majesties agent.

The Surveyor of His Majesties Workes.

The Clerke of the Hamper.

The Clerke of the Facultyes.

The Remembrancer of the First Fruits and Tenthes.

The Archbishops and Bishops for the tenthes and dismes of the Clergyr

The Keeper of his Majesties Privy Purse.

The Clark of the Pipe for the Profits of the Seale of the Exchequer.

At first sight it looks as if the distinction between the two types was, roughly, that accounts of revenue were taken by the Auditors of the Exchequer, while, as might be expected from their name, accounts of expenditure were the business of the Auditors of the Prests. It is to be remembered, however, that the practice of payment by assignment on certain specified branches of revenue made the distinction not a very clear one. Moreover, there are important exceptions. By a curious anomaly the Cofferer of the Household accounts in the old way. Secondly, the Hanaper, the Butlerage, the First Fruits and Tenths, the Faculties, and the Profits of the Exchequer Seal-all taken by the Auditors of the Prests-were primarily revenue accounts. The Mint accounts are omitted from both lists. 
A list belonging to the year 1621 among the Cranfield or Middlesex papers now at Knole usefully supplements the lists given above. It is called 'A breife of all the ordenary Accomptauntes before Sir Frances Gofton and Sir Richard Sutton knightes the twoe Auditors of the Prests'. It enumerates accountants by name, the particular methods used in the compilation of each account, and the extent to which the accounts were in arrears at the moment. A comparison between this list and the earlier one shows that there had been an important transference of business from the Auditors of the Exchequer to the Auditors of the Prests-namely the Customs Accounts. After the general farm of the Customs in 1604 known as the 'Great Farm', the Customers of the Ports no longer accounted in person at the Exchequer, and the accounts of the farmers were taken by the Auditors of the Prests. ${ }^{6}$ Moreover, the accounts of the important additions to the Customs Revenue under James I and Charles $I_{3}$ whether farmed or not, were also taken by them. The list of 1621 gives, in addition to the accountants specified in the earlier list, the farmers of the Great Custom, the Collectors of the New Impositions, the Collectors of the Pretermitted Customs, and the Collector of the Imposition of threepence in the pound payable by strangers. In a statement drawn up by the Auditors of the Prests in 1691 concerning the fees taken by them, the accounts of the farmers and collectors of the Customs are superseded by those of the Receiver General and Comptroller General of Customs.?

The next point to be examined is the date and occasion of the creation of the office of Auditor of the Prests. F. S. Thomas, in his Ancient Exchequer, gives the following account of its origin: ' The first mention of Auditors of Imprest (or Prest) was in the Court of Augmentations [i.e. Augmentations and Revenues] ..., and there they were styled Auditors of Prests and Foreign Accounts; and Article 29 of Annexation . . . plainly points out that that distinction was to be preserved for the future in the Exchequer-hence the origin of Auditors of Imprest.' 8 It is true that by the

- 'The fermors of the Great Customs and subsedics for the whole realme. . They accompte apon a certain rente and their defalcacions are by warrante of the Lorde Treasurer and Chauncellor and Barons.' Cf. Pipe and Audit Office Deolared Accounts. Nererthelese each of the seven auditors of the Exchequer was allowed a yearly foe of $f 18$ as a defalcation on the rent of the Great Farm $\rightarrow$ recognition of the vested interests of Exchequer officers in fees. This item appears regularly in the Declared Accounts of the Great Farm for the reign of James I. See also Lansdowne MS. 168, fo. $121 \mathrm{~b}$, Return of fees by the Auditors: 'By reason that the Customs nro in farme everie auditor is allowed for those accomptes rviiil yenrely'.

'See a peticion of the Auditors of the Prests to be allowed to retain their accustomed fees, 28 July 1691: Harl. MS. 6873, ff. 1-7.

- p. 124 (1848). 
establishment of the Court of Augmentations and Revenues there were ten Auditors of the revenues of the Court, two Auditors of the Prests and Foreign Accounts as well as two Auditors of Boulogne and Calais ; ${ }^{9}$ but the latter part of the explanation is quite inconsistent with the text of the article referred to, which runs :

The accounts of the Hanaper, the Butlerage, the Staple of Calais and the Revenue of the Customs there, the Prests, the Mint, the Great Wardrobe, the Customers of the Ports of Chester, Berwick, etc to be verily taken and engrossed by the Auditors of the Exchequer according to the ancient laws of the same Court, and as heretofore accustomed before the erection of the Courts of Survey and Augmentations. ${ }^{10}$

This is explicit. Fanshawe, who was Queen's Remembrancer from 1568 to 1601, states that 'those offices [the Auditors of the Prests] were first graunted by her Majestie'." Moreover, Mary actually pensioned off the officers of the Court of Augmentations and Revenues, including by name the two Auditors of the Prests. The warrant for drawing up the patents for the pensions begins :

Whereas we have dissolved our Courte of Augmentations and Revenues of our Crowne and have annexed the same and the possessions within the survey thereof to our Courte of our Exchequier by reason whereof divers of the officers of the said late Courte . . . are displaced of their servyce so that we ought to give them reasonable recompenses for their fees and commodities ...12

By the Articles of Annexation the number of Auditors of the Exchequer was raised from five to seven and their yearly fee from $£ 10$ to $£ 20 .{ }^{13}$ It was to be expected that the great increase in the volume of transactions at the Exchequer resulting from the dissolution of the Court of Augmentations and Revenues would lead to some modification of Exchequer methods. It did in fact lead to two important new developments. One, with which we are not here concerned, was connected with the management of the Land Revenue. The other was the addition to the

- Transcript of the Letters Patent establishing the Court, Land Rovenue, Miecellaneous Books, no. 113.

10 Thomas, p. 19, where the Articles are printed in full.

in State Papers, Dom., Eliz., oclv. 62 ; see below, p. 50. Cf. State Papers, Dom., James I, lxvii. 169: "The Auditors of the Imprestes . . . kept the Imprest accounts in their handes from $a^{\circ} 1^{\circ}$ Marie till the $39^{\text {th }}$ year of the late Queene, whoe apon complaint to the Lord Burghley ... that it was prejudiciall to the Crowne and contrarye to the ancyent Course of the Exchequer were by warrant and commandement under his handes and Sir John Fortescue the Chancellor of the Exchequer compelled to deliver all the said Accomptes remayning in theire handes to the Clerke of the Pipe which they have donne likewise ever since...'

" Copy of Sign Manual warrant, 4 May anno I : B. M., Cotton MS., Titus B. IV, fo. 131.

4 Article no. 30, Thomas, p. 19. 
establishment of the Exchequer of two Auditors of the Prests after an interval of six years. The patent of Elizabeth appointing the two first holders of the office in the Exchequer makes the matter clear. ${ }^{14}$

Sciatis quod nos pro certis bonis et rationsbilibus causis et considerationibus nos ad praesens specialiter moventibus ordinavimus . . q quod de caetero sint et erunt duo Auditores vocati et vocandi Auditores de Lez Prestes et Compotorum forinsecorum nostrorum.

The new auditors are to take the accounts of the Clerks and Surveyors of the Works, the Treasurer of the Ships, the Master of the Ordnance, and of all to whom money was issued in prest, and also of the Hanaper, the Great Wardrobe, and the Butlerage,

in consimili modo et forms prout huiusmodi duo Auditores pro cansis praedictis nuper assignati et appunctati fuerunt in Curia Augmentationum et Reventionum Coronae Regiae.

They were also to take the accounts of the revenues of the First Fruits and Tenths of the Clergy. The first patentees were to be Auditors of the Mint and Exchange, but from the wording of the patent this does not seem inherent in the office, though it afterwards became so. 18

The first Auditors of the Prests in the Exchequer were then appointed on 19 January 1559/60. This appointment may be considered as marking the end of the first stage in the development of the so-called Declared Account. Thus Auditors of the Prests were officers of the Court of Augmentations and Revenues. and while this court survived it dealt with those accounts which were afterwards taken by the Auditors of Imprest in the Exchequer. This is borne out by the extant accounts of that date. For instance, the account of Sir John Clere

Treasurer of his Majesties armye . . . beyond the seas . . . declared in ii particler Bookes and ... warrauntes . . . perused, caste, tried and examined by William Dixe and Gregorie Richardson ... Auditors of the Prestes, and declared before the Chauncelor and Generall Surveiors of His Graces Courte of thaugmentacions and Revenues..$^{16}$

At the dissolution of the court by Mary, their business was taken over by the Auditors of the Exchequer until the office was

\footnotetext{
14 Henry Coddenham and John Hamby, Rot. pat. 2 Eliz., part 3, 19 January. Mador has left, among his manuscript notes, a transoript of this patent from the Memoranda Rolls. His reference is Ex 2 parte orig. 2 Eliz. Rot. 35. See B. M. Add. MS. 4512, ff. 169-81.

1s See sbove, p. 42, note 3, and Lanedowne MS. 83, no. 76.

16 Declared Acoount, Pipe Office, 222, dated 21 May anno 4 Edward VI; cf. also Acoount of John Rowsley of viotuals for the fleet, 36-8 Henry VIII, Exchequer Acoounts, Various, bundle 531, no. 37.
} 
revived and introduced into the Exchequer by Elizabeth. ${ }^{17}$ The new auditors were then entrusted with those accounts which had been taken by their prototypes in the dissolved court, and also with the accounts of the revenues of the Court of First Fruits and Tenths dissolved by Mary.

A detailed examination of the origin of the methods of the Auditors of the Prests in the Court of Augmentations and Revenues is outside the scope of this paper. As the erection of that court by letters patent was only the culmination of a series of statutes, by which certain lands and certain classes of accounts were withdrawn from the normal procedure of the Exchequer, it is clear that the origin of the new method is probably to be found in the earlier changes of which the new court was the outcome. The statutes in question were based on the practice of Henry VII, by which debtors were ordered to account by word of mouth to Sir Reginald Bray, Sir Robert Southwell, and others, payments being made directly to the Treasurer of the Chamber instead of passing through the Exchequer of Receipt. ${ }^{18}$ By the act of 4 Henry VIII, c. 18, the accounts which were to be taken by the king's General Surveyors were specified as certain Crown lands, and the revenues of Calais, of the Great Wardrobe, the Hanaper, the Butlerage, and the duty of 68 . $8 d$. on the butt of malmsey wine. This list remains substantially the same in later acte. Finally, a separate court was created to deal with these accountsthe Court of General Surveyors. Those revenue accounts which were afterwards entrusted to the Auditors of the Prests were thus withdrawn at least as early as 1513 from the 'ancient course' of the Exchequer. This is confirmed by the examination of the accounts of those revenues for the period in question. For instance the Butlerage account for the year 1519-20 was declared before Sir John Daunce, one of the king's General Surveyors. ${ }^{29}$ It is signed ex[aminatur] per me Iohannem Daunce. The account itself was engrossed by one of the Auditors of the Exchequer, who received a fee of $£ 14$ for his pains. In its arrangement and spacing and in the use of long brackets it approximates to the form afterwards used by the Auditors of the Prests.

Imprest accounts as such are not specified in these acts. There is, however, evidence that the accounts for 'the wars' and 'the ships', for instance, were not going through the normal

17 e. g. Declared Account, Pipe Office, 477, a Butlerage Account for 1556-7, made up by one of the Auditors of the Exchequer (John Thomson), but in the manner previously used in the Court of Augmentations.

101 Hen. VII, c. $3 ; 3$ Hen. VIII, c. $23 ; 4$ Hen. VIII, c. 18; 6 Hen. VIII, c. 24; 7 Hen. VIII, c. 7; 14 and 15 Hen. VIIL, o. 15; 27 Hen. VIIL, o. 27 (Court of Augmentations); 27 Hen. VIII, c. 62; 33 Hen. VIII, c. 39 (Court of General Surveyora). Seo the preambles to these statutes.

11 Declared Account, Pipe Office, no. 455. 
Exchequer process, which started with the certificate from the Clerk of the Pell of money issued in prest, and ended with the Quietus est given by the Clerk of the Pipe on the final enrolment of the abstract of the account on the Pipe Roll. It is clear that the summary methods introduced by Henry VII and continued by Henry VIII left no room for such a process. In the first place the pell of issue was discontinued.20 Secondly, the accounts scattered through the State Papers of Henry VIII suggest a practice which ignores the course of the Exchequer. An instance of this is an account of the Treasurer of the Wars of the King's Army of the North in the year 1513. Payments were made by one of the king's chaplains, and by John Heron; the account itself is signed by the king. ${ }^{21}$ For the same year there is a list 'divers accountants' whose accounts were taken and declared before Sir Robert Southwell. It includes several Treasurers at War, a Clerk of the King's Works, and commissioners for taking horses and pressing carters.22

The origin of the methods of the Auditors of the Prests, then, can be traced in certain specified revenue accounts dealt with in a series of statutes which culminated in the erection of the Court of Surveyors; and also in the methods used by virtue of the king's authority in the case of certain spending departments or imprest accounts. Then the business of the Court of Surveyors, together with the imprest accounts and the business of the Court of Augmentations, was handed over to the Court of Augmentations and Revenues. ${ }^{23}$ In this new court the Land Revenue accounts were dealt with by ten auditors of the revenues of the court. Two auditors of Boulogne and Calais dealt with the revenues from French possessions, while the remainder of the accounts coming before the court were taken by the Auditors

\footnotetext{
- The account given by Sir Vincent Skinner (who was Auditor of the Roceipt or writer of the Tallies under Jamee I, and a great rival and enemy of the Clerk of the Pells) of the suppression of the Pell of Issue is intereating : Henry VII 'finding the confued obscurities of these Pelles and Counter Pelles . .. and that they were atterly unservice ble for his use when he would be informed how his revenue ame in or was issued out in severall natures to ... but with long serch and much charge in digesting and sorting the same out of thet rude and undigested chars by reason th'entries were made (Pesle Mesle) as the course of the Pelles is ...., suppresed these confused Pelles ...' Beo his tract, 'What the Auncient Course of the Receipt of the Exchequer hath beene...', annotated by Sir Julius Ceesar, in Lansdowne MS. 171, fo. $307 \mathrm{ff}$.

n State Papers, Henry VIII, i, no. 4375.

- Ibid. i, no. 4630 .

- The reason for this step is given in the patent erecting the new court : ' $\ldots$ Saoh antiquyties and dorts have rysen amongest our officers of the anid courts for lack of good rules and orders to them prescribed that they coulde not by any meanes knowe dyreotlie howe to order the seme accordyng to our expeotacion and their duties . . . a also ... [there has been] a greate number of su perfluous officers ... [and] a great confusyon and disorder in our said revenewe': Transcript of Letters Patent, Angmentation Offico, Miscellaneous Books, no. 17.
} 
of the Prests. ${ }^{24}$ From this it would appear that for some years the business of the old Exchequer of Account must have been reduced to little more than the Sheriffs' and Escheators' accounts, the accounts of subsidies and fifteenths, and presamably the account of the Cofferer of the Household, which curiously seems never to have been classed with the imprest accounts. ${ }^{25}$ These, then, probably were those 'revenues of the Court of Exchequer' which were definitely excluded from the survey of the new court. They were also those accounts which the Auditors of the Exchequer continued to take in their capacity of Auditors of ' ould Exchequer accomptes' until the accounts in question became obsolete.

The development of the system introduced into the Exchequer by the appointment of the Auditors of the Prests consists of the gradual elaboration of rules for the custody and passing of the accounts taken by them. The next stage was reached in 1597, when by Burghley's orders the rolls of accounts engrossed by the Auditors of the Prests were no longer to be retained by them, but were to be delivered into the Court of Exchequer to be preserved in the Pipe Office. ${ }^{26}$. The Auditors petitioned against this order :

In verie dutifull maner wee the Auditors of her Majesties Prestes do eftsones exhibite our humble petition unto your good honours concerninge the continuance of our office in such sorte as our predecessors longe before us and wee hetherto have enjoyed them, as well to other respectes in regarde to the great travaile incident thereto, as also for the custodie of the Recordes thereof reserved in a convenient and safe place assigned long since to those officers for that purpose within the precinctes of the Exchequer, readie alwayes to be produced, and the peculier state of everie such accompte to be sett out as at diverse times by our said predecessors and us hath bene performed.87

The petition had no effect. On 9 August 1597 one of the Auditors of the Prests wrote to Burghley,

Your Lordship having commaunded by warraunte that all the Accomptes of Imprestes should be delivered into the Courte (which is

14 By the establishment of the Court of Augmentations and Revenues 'the Audytors of the Prestes ' were ' to take the accompts of the warres buyldinge shippes ordynaunces and all other sommes of money delivered in prest and of the moneys and revenues of our hamper butleradge and the greate wardrobe': Augmentation Office, Mikcellaneous Books, no. 17. The mint acoounts were also taken in the court (seo the Articles of Anneration 29 quoted above), but are not specified as belonging to the Auditors of the Prests, a fact which probably explains their exarate treatment in the patent.

2s See below, p. 57, and the quotations from Fanshawe on p. 50 ; compare also retum of fees taken for making of accounts by Auditors of the Presta, Lansdowne MS.

26 State Papers, Dom., James I, lxvii, 169; see above, p. 45, note 11. This is corroborated by the two communications from Auditors of the Prests to Burghley, quoted below.

" Lansdowne MS. 83, no. 78.

VOI. XXXI.-NO. OXXI. 
done) . . I humbly pray that the specyalties concerninge eche accompte may remayne with the Auditor wherebye he maye justefye his doinges ... (any question hereafter arisinge).28

This order of Burghley's was probably the direct result of a long statement addressed to Elizabeth by Thomas Fanshawe, the Queen's Remembrancer, an authority on the Exchequer. ${ }^{29}$ His contention is

That the Accomptes of the Hanaper, Prestes, Mynte, Great Warderobe, and others ought to be delivered into the Courte and passe through the Remembrancers offices into the Clerk of the Pipe his office and there to remayne and the particulars of the same accomptes to remayne with the Queenes Remembrauncer like as the Accomptes of the Household and Customers and others be used, as appeareth by the Ordynaunces ${ }^{30}$ and the auncient Course of the Exchequer ... By greate numbers of particulers of the said Accomptes remayning in the custodie of the Queenes Remembrauncer and by the Accomptes engrossed and remayning in the Courte in the Clerk of the Pipes Office and by the takinges of the same accomptes in the Treasorers Remembrancers Office it appesreth that they were contynuallie so used untill the ereccion of the Courtes of Survey and Augmentacions. ${ }^{31}$

After the Auditors of the Prests had handed over their accounts to the Pipe Office there were still complaints that these accounts did not go through the stages required by the 'ancient course' of the Exchequer. Fanshawe, in his treatise on the Exchequer, addressed to Lord Buckhurst and therefore probably written between 1599 and 1601, writes as follows, contrasting the methods of the Auditors of the Exchequer with those of the Auditors of the Prests :

The King's Remembrancer receiveth from some one of the three barons and of the Auditors of the Court attending on them, all sheriffs forraign accounts, Collectors accounts of subsidies and fifteens, and the Cofferers accounts which he taketh, and the Accomptant's name with his addition of account and the summe totall and the debts of the same, and so putteth every of them ever by himselfe or one of the Clerks of his office to the Treasurer's Remembrancers side to be entred there in like sort: both which Remembrancers should likewise receive all the Great

1 Lansdowne MS. 83, no. 76.

"State Pepers, Dom., Eliz., oclv. 62, without date, docketed in R. Cecil's hand 'Concerning Debtes'. The peper is not aigned, bat is by 'your Mejesties most bamble servent and Remembrauncer of the Exchequer ...' See above, p. 45.

30 'By the ordynances sett foorth by kinge Edward the Second entered in the saide Red Book.' Soe The Red Book of the Exchequer, pp. 848 seq., and especially 933-5.

"State Papers, Dom., Eliz., cclv. 62. A shorter form of this document is in Lansdowne MS. 188, fo. 350, headed in Sir Julius Chesar's hand, 'The order for taking of imprest accomptes $6^{\text {th }}$ Nov, 1606'. In it the arguments againat the custody of accounts by Auditors are omitted, as this particular grievance no longer existed. 
accounts taken now before the Auditors of the Prests . . . to make like entrie thereof in both their offices, and to be conveyed in the viewes of every yeares remembrance and that he to whome it did appertaine might make processe upon the same where any cause should so fall out, and so noe super or debt thereupon by that meanes should be left behind to be out of processe every Terme while they were discharged. ${ }^{33}$

In the same book the Auditors of the Prests are described as follows :

The Anditors of the Prests be they that take the old great accounts of the Exchequer as Ireland Barwick the Mynt the Laan the Wars the Ships the Provisions the Hamper the Ordnance the Clerk of the Works and such like remembred before who now declared the same before the Lord Treasurer Chancellor and Under Treasurer only and be never entred in the Court of Exchequer nor examined nor written upon there as they were woont to be. .s $^{35}$

Sir Edward Wardoar, the Clerk of the Pells, writing in the earlier part of James I's reign, ${ }^{34}$ contrasts in some detail the methods of the old Compotus and the Prest account. He first describes the way in which, under the old system, the issue of money in prest was certified by constat from the Clerk of the Pells out of the Issue Roll or Pell of Issue. After this ' the Auditor proceeded with the Accompt, which beinge finished it was declared before the Lord Treasurer and Barons of the Exchequer or some of them ' ${ }^{35}$ The description of the next stages in the passing of the account he heads

All this orderly course following is now omitted. Then was the same accompt delivered to the Kings Remembrancer to make an entrie thereof in his office upon the State Rolles for such Accomptantes, and the bag of particulers to justefye the same accompte to be left there: And from thence the same accompt was delivered into the Lord Treasurers Remembrancers Office, upon which if there remained any super in the Accomptants hand, then did they send out proces for the same accordingly. After this the said Accompt was delivered to the Clerke of the Pipe to be entred with him of Record for the kings more assured service upon which if he [the accountant] had perfectly cleared his accompt he was to have his Quietrus est.

And last of all the Clerke of the Pipe did make upon the backe of the Accompt an irrotulatur in theis wordes irrotulatur ut patet in Rotulo xlio Rotu[l]o Compotorum de Anno xi Regis Edroardi tertii, upon sight whereof

a The Practice of the Exchequer Couth printed 1658.

a Ibid. pp. 83-4. In the manuscript version of Jansdowne M8. 171, fo. 423, the words in italios are emphasized by a vertical line in the margin.

36 'A description of the antient course that was used in the Exchequer by all accomptants that did receive money in prest for the king's service :' Lansdowne MS. 164, fo. 439, annotated by Sir Julius Cacar and docketed ' Exitus Wardour'.

4 After the reforms of Stapleton in the reign of Edward II, before one of the barons only. Cf. P. R. O. Lists and Indexes, nxx, Introduction. 
the Clerkes of the Pell did fill up the unde respondebit in the Pell of Exitus with theis wordes $E t$ respondebat in Compoto suo ad Scaccarium Rotulo xi, Rotulo compotorum de anno xi Edwardi tertii . . The Accomptant is much injured for that this antient orderly course is not nowe so effectually observed for his discharge as in former times it was, for nowe no Accomptant doth fetch any constat from the Clarke of the Pells certifyed out of the Pell of Exitus that his Auditor may se his charge by record. Neither doth the King's Remembrancer see any Prest Accompt or receive the bag of particulars, neither is there any Prest Accompt brought to the Treasurers Remembrancer's Office whereby he may send out proces as cause shall require, neither doth the Clerke of the Pipe enter any of the said Prest Accomptes of Record, as by the duetie of his office for his Majesties more assured service he ought to doe, neither is the unde respondebit discharged against the Accomptant in the Pell of Exitus which maie in time bringe great molestacion and expences to the Accomptant and his heires. And the officers videlicet the King's Remembrancer, the Treasurers Remembrancer, the Clerke of the Pipe, and Clerke of the Pelles are much hindred in the credittes and dueties of their services.

Fanshawe sums up clearly the objects aimed at in the earlier system and the dangers of departing from it :

the Particulers and accomptes being thus declared and passed according to the auncient course they shall have the ordinarie controlement' as others have, by remayning in the severall custodies of others then those that made them, as the particulers in one office, and the accomptes in another, and by beinge briefelie entered with both the Remembrauncers of Record so as no alteracion can be made, which sorte of Comptrollement seemeth by all presidentes to have byn used as necessarie in the whole course of that service from the beginninge. ${ }^{36}$

The same principle is laid down in an explanation of the nature of an account in a manuscript of the reign of James $I:{ }^{3}$

Both the auncient custome of this Court, and the common lawes of this Kingdome doe require that all accounts shall be made upon oath and declared before some judiciall officers therunto appointed. And after declaracion come to the viewe of the Kings and Treasurers Remembrancer, And lastlie to the custodie and controllement of the Clerk of the Pipe, who is to give allowance of the same if the dedications by tally or otherwise ... will endure the touch. ${ }^{38}$

There were then a considerable number of complaints after 1560 that the Prest accounts were not passed according to the

3* State Papers, Dom., Eliz., colv. 62.

27 'A Reconciliacion made between the King and his Subjectes touching the Demaunde of his Right in old Debts' (temp. James I) : Cotton MS., Titus B. IV, fo. $1 \mathrm{ff}$. Other copies are in Add. MSS., 11764 and 25250.

18 There is a marginal note to this: 'the nature of an account, rub. et niger in $\operatorname{cc}[a c k[a r] i 0 . '$ It is to be noted that the eventeenth-centary Exchequer men, in their explanstions of the 'nature of an account' and 'the Ancient Course of the Exchequer', taoitly omit the Sheriff's Pipe Roll account as a thing apart. 
'Ancient Course' of the Exchequer. ${ }^{39}$ In 1597, probably as a result of the representations of Fanshawe, the Auditors handed over the accounts to the custody of the Clerk of the Pipe. After this complaints continued to be made that the accounts did not pass through the offices of the two Remembrancers. It was not until Juxon's Treasurership (1636-41) that an Exchequer order was drawn up 'concerninge the entring of the Great Accomptantes Accounts with the King's Remembrancer'.40 The cause of the order was stated to be that the King's Remembrancer, being kept in ignorance of the state of the accounts in question, was neither in a position to make process against the accountants to force them to come to account when they were in arrears, nor to cease process when the accounts were duly settled. ${ }^{11}$ This point had been urged by Fanshawe in his memorandum to Elizabeth. The order runs: " the said ancient course hath been disused and discontinued and the said accomptes ${ }^{12}$ have beene carried to the Pipe Office and never brought to the office of the Kings Remembrancer nor in [sic] the office of the Lord Treasurers Remembrancer as all other accomptes of that nature have formerly used to bee...'

Certain points appear from or are suggested by this succession of documents relating to the Auditors of the Prests. It is clear that a new system was introduced into the Exchequer in 1560 based on that which had been used in the Court of Augmentations and Revenues. It is also probable that the two Auditors of the Imprests were from the first intended to have a position superior to that held by the seven Auditors of the Exchequer,

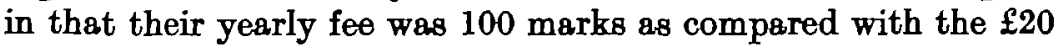
of the other auditors. ${ }^{43}$ The accounts taken by the Auditors of

"Soe a specimen addressed by Fanshawe, State Papers, Dom., Eliz., colv. 62 (1595 ?): 'Maie it please your highnes moste grecions soveraigne myself your Majesties moet hamble servant and Remembrancer with some other of the best experienced in that Courte seeing the Accomptes of Prestes and some other greate Accompter to be made kept and used and debte thereupon growing be delayed after an undue course to your Majesties losee and the hindrance of your Majesties Accomptantes, as weo then thought did about $\mathrm{nx}^{\mathrm{t}}{ }^{10}$ yeres agoe upon conference amongst our selves, sett downe proofes that those Accomptes ought to have byn made kept and used according to the auncient conrse of that Courte.'

4. 'Dranght of an order concerning the entring of the Great Accomptants Accounts with the Kings Remembrancer :' L. T. R., Miscellaneons Books, 118, fo. 230. This is the same precedent book from which the list of accountents on p.42 is taken. a Ibid.

a The acoounts are specified in the order as "The Treasurer of the Chamber of our Soveraigne Lord the King, the Master of the Great Wardrobe, the Surveyor Generall of the Victualls for Sea Causes, the Treasurer of the Navy and diverse other Great accomptantes to his Majestie.'

42 Judging from the pensions allowed, the contrary seems to have been the case in the Court of Augmentations and Revenues. At the dissolution of the court the

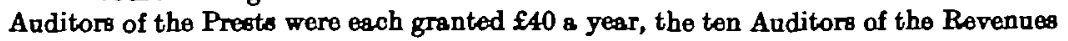
sums varying from 1200 a year (this was to Thomas Mildmay) to $£ 50$ a year, the most ustal amount being 200 marks : Cotton MS., Titus B. IV, fo. 131. 
the Prests, moreover, were gaining in importance with the expansion of revenue and expenditure, while those taken by the Auditors of the Exchequer were both absolutely and relatively declining. After the Restoration these latter-apart from the land revenue accounts which they took docally-found themselves mainly controlling accounts which were becoming formal or obsolete-namely, the sheriff's foreign account and the accounts of the collectors of subsidies-fifteenths and tenths having already fallen into complete disuse. ${ }^{44}$ Then there was a tendency to entrust new types of account to the Auditors of the Prests. This is seen in the case of the accounts of the farmers and collectors of the Customs, who after 1604 replaced the customers as accountants at the Exchequer. The tendency of Exchequer officers was to resist all innovation, so that a consistent pressure was exerted to subject the new system to the same checks as the old. It seems probable that the intention of the change was to substitute a more thoroughgoing declaration, and a fuller and more explicit type of account for which two auditors were jointly responsible, for the old system of check and countercheck by the retention of the bag of particulars and the multiplication of entries.

The conservatism of Exchequer officers was a natural consequence of their conditions of service and is clearly expressed in their writings. For instance,

the orders and rules for the governance of the king's revenewes in the Exchequer being by the wisedome of our ancestors thus setled and regulated and sondry strict provisions and declaracions having theruppon byn from tyme to tyme made for the due observacion thereof by each officer that none should presume to violate and infringe the same in the least, it was to that end decreed and ordered that none but sadd men sueh as had byn bredd and brought upp in the said court from their youth, should be admitted to buy any of those places concerning the charging and discharging of the kings revenues. 45

\section{And again :}

Beholde then the quintessence of all invension in the methode of this Court . . . soe perfect it is in all points that the best witts cannot finde what to adde or take awaie in anie particuler without injurie to the whole.46

4 The Anditors of the Frohequer, however, took the acoounts of the Land Tax and Asesesed Taxes which superseded the eubsidy : Thomas, The Ancient Exchequer, pp. 84-6.

4 'The Platforme of the Erohequer The Abuses and the Remedyee,' Harl. M8. 3796, fo. $1 \mathrm{ff}$.; endored 'rece[ived] May 27't 1635.'

11 'A Roconoiliacion made between the King and' his Subjeotes touching the Demaunde of his Right in old Debtes ' (temp. James I) : Cotton MS., Titus B. IV, ff. 16. See also the preamble to a schedule of inquiries touching abuses directed to the officere of the Exchequer a little later: "That aince we finde by daily experienoe that the king and subject are alike wronged if the Ancient Course and Ordinances of the Exchequer be not obeerved. And that it is concested the witt of man cannot invent 
Moreover, the system of Exchequer fees made changes in the direction of simplification almost impossible. A fee was paid for each entry and enrolment, so that the two Remembrancers and the Clerk of the Pipe suffered direct money loss from the omission of entries of accounts in their offices. The losses were the greater hardship in that offices in the Exchequer were bought, and were in the nature of a freehold, the value of which was based on a computation of the annual fees taken from accountants and others. ${ }^{47}$ The Queen's Remembrancer, Fanshawe, had thus a pecuniary incentive to his protests against the innovations in the Prest Accounts over and above the natural conservatism of the Exchequer official.

It should be noted that there is nothing in any of these Exchequer orders and descriptions of Exchequer methods which explains the paper duplicate of the account preserved at the Audit Office. It is not referred to in the correspondence between the Auditors of the Prests and Burghley relating to the handing over of the accounts to the Pipe Office. On the contrary, the auditors plead

that if the asid Recordes nether shalbe impayred in credite of the true purporte thereof by remayninge with us nether yet shoulde adde anie more force of trueth if they were transposed from us into an other mannes custodie, ${ }^{\text {cs }}$

a contention which would have had no force if the Audit Office copy had existed at that time. What does appear from that correspondence is that the Auditors of the Prests had, down to that time, kept the accounts compiled by them and were thenceforward obliged to hand them over on completion.

They had, however, probably always made two copies of each account, one being a duplicate for the accountànt. Fanshawe urges that accountants

should not be forced to take duplicamentes, as nowe is much unnecessary tyme is [sic] spent and the accomptants ... put to greate chardge by longe attendance and the making of those longe accomptes with their duplicamentes. ${ }^{19}$

The explanation which suggests itself is that after 1597 the Auditors of the Prests consistently made three copies of each

a better my for preventinge the knowne mischiefes and inconveniences of that Court then to restore and renovate the Aunoient Couree of the said Court bounding it there with striote limitacions and penalties and abolishing all innovacions lately orepte into the same' : L. T. R., Miscollaneous Books, 118.

a Compare a discuesion in the House of Commons on a bill to reduce the feer of Erohequer officers, 20 May 1014: 'Mr. Ashley . . . that both inconvenience and danger in these bille. Inoonvenience in taking all fees whioh the froehold of the officers ': Commons' Journals, i. $490 \mathrm{~b}$.

4L Lansdowne MS. 83, no. 78. "State Pepers, Dom., Eliz., colv. 62. 
account, one for themselves on paper, the Audit Office copy, one for the Pipe Office (which was strictly speaking the record), and one for the accountant, the last two being on parchment. This had certainly become their settled practice by the end of the seventeenth century. ${ }^{50}$ An examination of the Record Office List of Declared Accounts shows that in the case of accounts made up after 1597 both Pipe and Audit Office copies are usually found, while before that date, in many classes of accounts, there is as a rule either a Pipe Office or an Audit Office copy, but not both. In some classes, however, duplicates are frequent from about 1560 onwards-for instance, in the accounts of the Hanaper, of the Navy, and of the Treasurer of the Chamber. What is the explanation of such duplicates? Possibly they are the copies made for accountants which were never handed over to them, either from some accident or because the required fee was not forthcoming. It is also a fact that one of the puzzles connected with English records is that there are a certain number of unexplained duplicates in most large classes of documents.

It appears, then, that the type of account which became known as the Pipe and Audit Office Declared Account is the resultant of several distinct forces. At first the innovations of Henry VII and Henry VIII removed certain classes of account from the normal routine of the Exchequer and led up to the methods of the Court of Augmentations and Revenues. Then the methods of this court were designed by Elizabeth to be introduced into the Exchequer. These methods included a new manner of spacing and arrangement in the text of the account, a declaration before the chief officers of the Court, and probably the delivery to the accountant of a duplicate of his account, this last.being apparently a substitute for the quietus est of the earlier system.si The protests of the 'Exchequer men' succeeded in bringing these new methods partially into line with the 'Ancient Course

\footnotetext{
so Soe a Treatise on the Exchequer by Mr. Lionel Herne (first Clerk to one of the Tellers, died 1714): "For every acoomptant they make three accompts which are by them engrosed . . a and signed by the Lord Treasurer and Chancellor . . . whereof one is for the perty another for themselves and the third is to be delivered into the Pipe Office where it is to remaine for a Rooord,' Harl. MS. 3278. Compare also a Petition of the Auditars of the Preets, 28 July 1691, Harl. MS. 6837, fo. 1: 'the severall accounts before mencioned (except those of the Tenths of the Clergie) . . aro once faire written in paper, and trice engrosesed on parchment.'

s The duplicate seems to have been a substitate for the Quietrus est which was a copy made in the Pipe Office of the sammary enrolment of the account on the Pipe Roll. Fanshawe complains that as there was no entry with the Clerk of the Pipe, there could be no quietus :est: State Papors, Dom., Elix, oclv. 62. The writer of a pamphlet published in 1862 complains that Auditors have given accountants insignificant discharges and foroed them to teke duplicates of their whole acconnts becaure they had no power to give a quietus est. 800 "An Answer to a paper called the Case of the Auditors and Receivers of his Majesty's Revenue. With a brief description of the entient Course of the Exchequer', by W. G., London, 1862.
} 
of the Exchequer'. They secured the handing over of the accounts to the Pipe Office, and eventually the entry of accounts with the King's Remembrancer. It may be suggested that the Auditors of the Prests themselves, in support of the security and dignity of their office, introduced the practice of making an Audit Office copy as well as the original version which from 1597 onwards was deposited in the Pipe Office.

There were then in the Exchequer after 1560, broadly speaking and omitting minor variations, three types of accounts engrossed by the Auditors in the Exchequer. There were, first of all, the surviving examples of the old foreign account-the compotustaken according to the Ancient Course of the Exchequer. The essential features of this were that after declaration it should pass through the King's Remembrancer's and Treasurer's Remembrancer's offices, and finally be enrolled on the Great Roll of the Pipe, when the Accountant could receive his quietus est if his tallies were satisfactorily joined. Secondly, the accounts of the Land Revenues taken by these same auditors, each of whom had certain counties assigned to him in his patent. These accounts were taken 'Augmentation-like' and not according to the Ancient Course of the Exchequer; a thing much complained of in the seventeenth century. ${ }^{52}$ As time went on the Land Revenue Accounts became so much the most important part of their business that they became generally known as the Auditors of the Land Revenue. In 1706 their number was reduced to three. ${ }^{53}$ Thirdly, there were the accounts taken by the Auditors of the Prests, which became known as Pipe and Audit Office Declared Accounts. ${ }^{\circ}$

The question arises as to how the so-called Declared Account differs from the earlier Compotus. The difference will be plain to any one who compares a Pipe and Audit Office Declared Account properly so called with an account of the period before the innovations of Henry VII and Henry VIII, or with one of those accounts which continued to be taken by the Auditors of the Exchequer in the old way-say a Sheriff's Account of Seizures or an Account of the Cofferer of the Household. The Declared Account is written in a different hand and is arranged much more clearly,

- For instance, in 'A Short Introduction to the better understanding of the Exchequer' (temp. James I), Add. M8. 36081; Vernon, Considerations for regulating the Exchequer, printed in 1642; 'A Reconciliacion made between the King and his Sabjectes touching old Debtes' (temp. James I), Cotton MS., Titus B. IV, fo. 1 ; ' An Answer to the Case of the Auditors and Receivers of his Majesty's Revenue,' by W. G.; 'Argaments to prove that the Accounts,' \&o., State Papers, Dom., James I, livii. 168.

w Thomas, p. 125.

4 The Auditors of the Impresta were succeeded in 1785 by the commissioners for auditing public accounts: First Report of the Committee on the Public Records, 1800, p. $132 b$. 
this clearness being chiefly due to spacing and the use of long brackets with marginal figures. But the essential distinction is that the Declared Account is signed at the foot by the two Auditors of the Prests in the following form :

$$
\left.\begin{array}{r}
\text { Exr per nos Ri: Sutton } \\
\text { Fra Gofton }
\end{array}\right\} \text { auditores. }{ }^{66}
$$

The earlier type of account is headed by the names of the baron before whom the account was declared and of the auditor who made up the account. These names are not signatures, but are written in the same hand as the text of the account in the following way:

$$
\text { Auditores }\left\{\begin{array}{l}
\text { Robertus Malton, Baro. } \\
\text { Thomas Beneyt Clericus. }
\end{array}\right.
$$

The two types of account, as we have seen, continued to exist together ; the differences of form were a natural outcome of the fact that each had its origin in a different office of the Exchequer, with a different tradition, methode, and handwriting.

\section{Dorothy George.}

st Pipe and Audit Office Declared Acoounta, James I, paserim.

st Thus Exchequer Acoounta K. R., bundle 215, no. 4, a Hansper Acoount, 1-2 Henry VI. The later acounts of the Cofferer of the Household are headed by the names of the Treasurer, Chancellor, some of the barons (who are all bracketed auditores), and by two Auditors of the Exchequer braoketed as clerici. Thomas ang that these acoounts were taken in full court, op. cit., p. 85. 